\title{
粗
}

\section{The reformed confessions and church membership ethically appraised}

\author{
Herm J.G. Zandman \\ School for Ecclesiastical Sciences \\ Potchefstroom campus \\ Nort-West University \\ POTCHEFSTROOM \\ E-mail: zandman@ozemail.com.au
}

\begin{abstract}
The reformed confessions and church membership ethically appraised
\end{abstract}

The reformed churches historically call themselves confessional churches, with the confessions adopted by church councils being the yardstick according to which membership is either permitted or refused. The reformed churches consequently consider it necessary for all members of the church to express agreement with the confessions. The reason why the confessions are held as the summary standard of belief is founded in the conviction that they are faithful expressions of the teachings handed down from the apostles.

These confessions have been attributed a twofold purpose regarding their function in the reformed churches. Firstly, they protect believers and congregations from error, and secondly, they help attain unity of faith among the believers in the reformed churches - both at the congregational and denominational level.

Currently this view is under siege from those who hold the conviction that the traditional approach of giving the confessions such prominence is too narrow and binding in terms of who may or may not be awarded membership of the reformed churches.

This article seeks to consider the place of the confessions and to evaluate the claim that de-emphasis on the confessions is desirable in order to celebrate the unity of all believers. Furthermore, the article seeks to demonstrate that ethical integrity is contingent on seeking to exercise church 
government within the demarcation of the confessional framework.

\section{Opsomming}

\section{'n Etiese waardering van geloofsbelydenisse en kerklidmaat- skap in die gereformeerde kerke}

Histories beskou die gereformeerde kerke hulleself as deel van die belydende kerk. Gevolglik is dit op grond van die spesifieke belydenis wat deur 'n kerk se kerkraad aanvaar word dat persone lidmaatskap van die genoemde kerk aanvaar of geweier word. Juis daarom beskou die gereformeerde kerke dit as 'n vereiste dat elke lidmaat van die kerk hom/haar vereenselwig met die geloofsbelydenis van die kerk.

Die rede waarom die geloofsbelydenis beskou word as die standaard waarvolgens geoordeel moet word, is gebaseer op die oortuiging dat die belydenisse die getroue uitdrukkings is van die leer van die apostels soos wat dit aan ons oorgedra is.

Daar bestaan 'n tweërlei doel met betrekking tot die funksie van belydenisse in die gereformeerde kerke, naamlik om te waak teen wanbegrip en om eenvormigheid van geloof tussen gelowiges in die gereformeerde kerke, sowel in die gemeente as in die denominasie, te verseker.

Tans word hierdie beskouing bevraagteken deur dié wat oortuig is dat die tradisionele benadering om die belydenisse as 'n hoogs belangrike maatstaf te beskou, te eng en te bindend is in terme van wie lidmaatskap van gereformeerde kerke mag geniet en wie nie.

Die artikel poog om die plek van belydenisskrifte te ondersoek en om die bewering dat dit nodig is om die belangrikheid van belydenisskrifte te verminder sodat eenstemmigheid van alle gelowiges bereik kan word, te evalueer. Verder poog die artikel om daarop te wys dat etiese integriteit van die uitoefening van kerkregering binne die grense van die belydenisse afhang.

\section{Stating the problem}

With the plethora of denominations currently present on the landscape of what is called the worldwide Christian church, along with the ecumenical movement that strives to restore unity among these denominations, there is much potential for confusion regarding the question of who to admit to membership in ones denomination. This is particularly the case when that denomination boasts of being a confessional, reformed church. 
The reformed churches historically call themselves confessional churches, with the confessions adopted by church councils being the yardstick according to which membership is either permitted or refused. The rationale behind this church policy has always been (Eikelboom, 1998:12-22) that the confessions are regarded as true reflections of - though never equal to - the Biblical teachings as set forth by the apostles (De Jong, 1980:47). Consequently these confessions have to provide for doctrinal purity as per the apostolic teachings, and have to form the bond of unity upon which those who oversee the flock, namely the reformed congregation of Jesus Christ in every locality where the church gathers, base membership. Moreover, the confessions also provide the framework within which the elders should operate so as to ensure ethical integrity and objectivity. This provides a guideline according to which the doctrinal maturity and resultant ethical consistency of fellow church members is continually being evaluated as part of overseeing the flock of the Lord Jesus Christ.

With the growth of the ecumenical movement, this stance has been regarded as Biblically unwarranted, sectarian even, by those who claim that anyone who confesses Christ as their Saviour and Lord ought to be admitted into the local body of believers, regardless of the denominational nameplate. After all, if a person professes to believe in Jesus, then it would be haughty to question this and, consequently, refuse such a believer the privilege of joining the local church of the same Lord Jesus.

The result of such reasoning, as far as many reformed church congregations (denominations) are concerned, is that those who do not fully adhere to the confessional standards of a particular reformed church are increasingly permitted into membership by the overseers, as the latter are of the viewpoint that they do not have Biblical grounds to refuse such membership. Subsequently, the keys of the kingdom (Matt. 16:19) now fit into doors that are wider than ever before in the history of the Reformation. Not only is the membership approach affected by this manner of thinking, but access to the Lord's Supper also undergoes a necessitated change. This is so because the same dilemma of judging a person's standing in Christ occurs when someone unknown to the overseers presents them with the request to join the Lord's Supper table at which the unity of believers with Christ and with each other is celebrated. This has resulted in an ever increasing slackening of supervision over the Lord's Supper, permitting admittance to all who profess Jesus Christ as Lord and Saviour apart from any specific confessional framework. 
The aquarian drift of popular thinking has now infiltrated the church. It has led the clergy to an emphasis on the immediate, which neglects history and tradition. It has led to an emphasis on emotional togetherness in delight, as opposed to controlled obeisance in worship. In the same way, the post-Christian mind tends to reject concepts that can be said to be in any way "exclusive". It will not have frameworks established that confine and restrict (Blamires, 1999:18, 32; Green \& McGrath, 1995:175-182; McGrath, 1995:128-132). Much of the argument of this article has been drawn from older sources, because the very notion Blamires sets before us has led to much theological writing advocating the widening or removal of frameworks (Jones, 2001:41-51).

This article endeavours to address the thinking of those who dare not presume upon a person's profession and, resultantly, open wide the doors to both membership and the Lord's Supper celebration. I will do this by considering the place of the reformed confessions in relation to the Scriptures and church, by weighing up the consequences of conclusions drawn for the ruling of the congregation by overseers, and by offering a consistent membership policy flowing from this. Furthermore, I will consider the phenomenon of denominationalism and how reformed church members and their overseers should regard other denominations.

In conclusion, I will present and analyse the reasoning of the wideembrace proponents in order, firstly, to arrive at a clear understanding of what their thinking is based on and, secondly, how to present sound, Biblical apologetics in the case of their expressed desire to expand church membership beyond confessional parameters.

\section{The Bible, the confessions and the church}

\subsection{Paul's reason for pronouncing a curse}

In Galatians 1:6-12, Paul writes the following:

I marvel that ye are so soon removed from him that called you into the grace of Christ unto another gospel: which is not another; but there be some that trouble you, and would pervert the gospel of Christ. But though we, or an angel from heaven, preach any other gospel unto you, let him be accursed. As we said before, so say I now again, if any man preach any other gospel unto you than that which we have preached unto you, let him be accursed. For do I now persuade men or God? or do I seek to please men? for if I yet pleased men, I should not be 
the servant of Christ. But I certify you, brethren, that the gospel which was preached of me is not after man. For I neither received it of man, neither was I taught it, but by the revelation of Jesus Christ (KJV).

Paul was very upset with the Galatian churches, because the believers in those churches followed after false teachers, teachers who did not faithfully expound the gospel as it was delivered to believers by means of the apostolic message, which is "all the counsel of God" (Acts 20:27). This message contained many teachings offensive to natural man, notably those so excellently summarised in the Canons of Dort, centring on the emphatic message that man is saved by grace alone, through faith. With regard to the veracity of the apostolic message, he provides credentials beyond doubt, namely that the apostles' word to them was received from the Lord of the church Himself. It astonished him that the believers actually went away from that message to follow a counterfeit. Let it be noted that the message they opened their ears to was not an entirely different gospel. Rather, it was a subtly twisted one, having just some changes in it, but enough to cause Paul to be very upset indeed (Flinn, 1985). The apostolic teachings were made light of and heresies slipped into the believers' understanding. Paul curses those who introduce such things, as they pervert the teachings handed down to the apostles by the Lord of the church, polluting the purity of teaching and destroying the unity of believers as a consequence. He also rebukes the members of the congregations who entertain such misleading teachings and tells them to turn back to the true message they initially received from him.

The Lord Jesus Christ Himself makes it very clear that those who know Him and are known by Him will hear his sayings and adhere to them (cf. Matt. 7:22-27; Luke 6:46-39). The Lord, so John Murray emphatically claims, will not countenance anyone to change or twist what $\mathrm{He}$ has given to the church and then present it as coming from Him. Those who entertain such desires have no part in Him. More seriously still is the fact that they influence the gullible and deceive them into believing what is counterfeit and, resultantly, futile, because it is not of the Lord, it is not the apostolic message. Division within the church arose from unfaithfulness to Christ and declension from the apostolic pattern (Murray, 1976:275).

It is evident from the aforesaid that those who know Christ know Him through the teachings of Scripture as given to the church by the 
apostles, who, in turn, received their message from the Lord of the church Himself (cf. John 17:20).

Throughout the history of the church, many deceivers have come on the scene, taking the Scriptures and changing the message, thereby attempting to lead many astray. While this was happening, the church was called upon to defend itself against such attacks from within in order to maintain the veracity of teaching. To that end church councils came together and drew up statements designed to refute error and to keep the church teachings true to the initially received message. Such statements are the various creeds (from the Latin word credo), which are also - and with good reason called forms of unity. All these documents had the purpose of defending the teachings of the church and maintaining unity of doctrine among the believers. One author put it as follows:

Religions have general and eternal truths for their object; they cannot therefore shape themselves to the shifting inclinations of every age without forfeiting their claim to certainty in the eyes of mankind. Religions are obliged to hold to the principal opinions which constitute a creed, and which theologians call articles of faith (De Tocqueville, 1832:153).

\subsection{The place of the confessions}

Following from this, it may be stated that the genuineness of faith becomes evident in confessions, as through them outward evidence is provided for the fact that truth has taken possession of the hearts of believers and that there is a Scriptural relationship to Christ in existence. The confessions of the apostolic faith naturally obligated the Church to distinguish between truth and falsehood, especially since they were formulated in the face of error and corruption. The Bible has been in the world for approximately twenty centuries, and during all those centuries learned and truly devouted men have been searching the Scriptures and have been endeavouring to summarise what the Scriptures teach (Gresham Machen, 1936:3538). The brightest minds and the choicest spirits have found their most exalted occupations in seeking to fathom the profound ways and thoughts of God (Hospers, 1924:3). It would be a mistake for a man who desires to present what the Bible teaches to neglect what the church has thought and done during all these centuries. Gresham Machen (1936:36) declares that the collective wisdom of the church, under the guidance of the Holy Spirit, has found its expression in the great Christian creeds as they have come down through the ancient creeds, through Augustine, and through the 
Reformation. Thus, the pure line of apostolic truth was preserved notably the type of doctrine that marks the reformed faith as expressed in the writings of John Calvin (Gresham Machen, 1940:1, 2, 8-10).

In the confessions of the reformed faith one does not find expressions of subjective, Christian experiences, but summary statements of what God has told the church in his Word. The fact that the reformed churches have continued to develop further confessions since the heydays of the Reformation is simply because doctrinal advance proceeds in the direction of greater precision and fullness of doctrinal statement (Gresham Machen, 1936:35-38). They, i.e. the confessions, were intended to set forth Biblical teaching in sharp reaction to the things that oppose Biblical teaching in order that the purity of the church might be preserved (Gresham Machen, 1936:36).

Let it be categorically stated that the reformed churches have never placed the creed beside or above Scripture (Ganz, 2005:1). The creed is always subject to the test of God's revealed Word, as is adamantly declared by the confessions themselves (cf. Belgic Confession, art. $5 \& 7$ ). Yet, the Reformation attributed authority to the confessions because it was convinced that whatever it professed in the confessions was wholly based upon the Word of God (Murray, 1976:280-281).

The reformed churches have consequently considered it necessary for all members of the church to express agreement with the confessions. They cannot consider their own individual witness to Christ as independent of the witness borne by the branch of the church to which they belong (Murray, 1976:275). Furthermore, the elders of the church have the right, the duty even, to judge the convictions of the church's members according to the confessions, because the confessions are the expression of a commonly held faith according to apostolic teachings. A church that does not uphold its confessions does not give proper nourishment to its sheep, permits them to wander in wrong paths, and runs the risk of dying out (Gresham Machen, 1936:35-38).

Arbitrariness in doctrine is divisive: stability in doctrine produces unity and builds the church. The elders as a body are responsible for guarding the gates of the church. They exercise the keys of the kingdom for binding and loosing (Matt. 16:19; 18:18). It is here that many elders fail. According to Eyres (1983:94-95), they are either unable or unwilling to render judgement for Christ. Elders must 
recognise that the church under their government is Christ's, not theirs. Christ insists that $\mathrm{He}$ be known as per the apostolic teachings. The confessions have this as their sole concern. The elders handling the confessions ought to have this as their sole concern as well. This is reflected in the preaching from the pulpit in that such preaching sets forth the counsel of God as per the apostolic message and, ipso facto, as per the confessional standards of the church.

This should also be seen in the home visits, since elders go into the communicants' homes with the message "Thus saith the Lord" (Bavinck, 1980:52). A manifest lack of conscious and consistent submission to the official (i.e. as per the confessed position) preaching of the Word from the pulpit is a matter of grave concern (Eyres, 1983:143-144).

One argument mounted against such a professed grave concern is the perceived "higher unity in Christ", which is said to be denied by this staunchness. More will be said about this later, but let it be stated for now that it is a wrong approach to place a higher unity in Christ (i.e. with believers outside one's own church and sister churches) over against the confessional and organisational unity in the reformed churches. Such a concept tends to break down church walls built upon the foundation of Scripture and confession. It tends to undermine obedience to the Lord in matters of church membership, to diminish ecclesiastical faithfulness and sincerity. It so easily brings confusion in the congregation. If separating church walls is a matter of obedience to God's Word in accordance with the adopted confession of the church, which is based on Scripture, it is the calling of the churches to maintain those walls, both for the church federation and for individual members (Geertsema, 1986:142-143).

\subsection{The church functions in submission to Christ}

No-one would disagree with the title of this section. Yet, when properly understood, the words "in submission to Christ" have deep ramifications. It is necessary to recognise that wherever believers are gathered together in accordance with Christ's institution and in his Name, there is the church of God. All the functions, prerogatives, and promises that God has accorded belong to that church, as Murray points out. The local church is the pillar and foundation of the truth (1 Tim. 3:15), in Christ providing access to the fullness of grace and truth (cf. John 1:14) and the treasures of wisdom and knowledge (Col. 2:3) of Him who is all in all. This means that the 
saints in the body of Christ have an ontological union with the Head, so that all He possesses becomes ours (Murray, 1964:324-325).

The saints' belief is not a faith that can be abstracted from the total witness of the New Testament to the identity of Jesus. Our Lord pointed to this when He said: "I pray for those who believe in Me through their word" (John 17:20 paraphrased). The apostolic witness is the teaching of Jesus (cf. Acts 1:1), and the unity professed is founded in unavoidably visible confession, void of fragmentation, marked by solidarity (Murray, 1964:334-335). It is not enough to profess involvement with $\mathrm{Him}$, if we do not consciously conform to his will and serve the interests of his kingdom. We will be cheating ourselves if we think that a bare profession of religion will save us (Henry, 1721:645-646).

From all that has been stated up to this point one must conclude that to declare belief in Christ is in and of itself not sufficient as a profession of faith. Echoing the Lord of the church, the apostle Paul insists that the professor must declare that he embraces the doctrines set forth by the apostles (Gal. 1:9). Christ is brought to his people through the teachings of Scripture. The message handed down to the apostles for Christ's followers to believe declares how we should live lives of thankfulness. God-fearing and discerning saints developed confessions over the centuries to defend the purity of the church against error and falsehood, to bring the church continuously back to its apostolic roots, and to safeguard the unity of the congregation as founded on apostolic teachings. The undershepherds should exercise rule over the flock in imitation of Christ, maintaining the doctrines that Christ and his apostles insisted on. The elders act presumptuously and take false refuge from their failure when they do not bring the various facets of the teachings jealously to bear upon Christ's honour and will, when they seek to conduct the government of the church (Murray, 1964:340).

The government of the church is one under the auspices and direction of apostolic witness (Murray, 1964:341). Therefore, to make professed adherence to Christ the norm for acceptance into church membership is the wrong premise from which to work. Rather, given that a person professes such adherence, the crucial issue ought to be how this adherence is being articulated: i.e. is it an adherence borne from the apostolic teachings regarding Christ? This was rightly stated by the keynote speaker at a conference (Snook, 2005:2): "Everybody will agree with the generic concept. However, when it is particularised and applied as it is intended, then 
generic concepts suddenly start to bite, because now they concern the person who is you."

\section{Consequences for the ecclesiastical landscape}

Ideas have consequences (Weaver, 1984: Introduction). The moment people latch onto particular conceptual positions, such as owning the teachings of the apostles, this has consequences for actions, for relationships, for the manner in which ethical situations are viewed given particular paradigms.

\subsection{Denominationalism}

\subsubsection{Denominationalism is undesirable}

Ideally, there ought to be one Christian church throughout the whole world, the church of Christ - one in doctrine, one in worship, one in government, and one in discipline. Everyone imbued with zeal for the honour of Christ must deplore the fragmentation that has marred the body of Christ, and to a large extent, dissipated its witness (Murray, 1976:275). Denominationalism, the division of the professed Body of Christ on account of differing interpretations regarding doctrinal teachings, is an evil, and it is a shame on the church (Flinn, 1985).

But, because of sin and error in their manifold expressions, division has arisen and, under the circumstances, division has been mandatory for the preservation of pure witness and the promotion of that unity which alone is worthy of the name "the unity of the Spirit in the bond of peace" (Murray, 1976:275). The confessional walls that have been erected are a sad testimony to the fact that even the church of Christ is suffering the consequences of the curse under which moving away from God is an ever-present danger (Gen. 3:67). However, the believers who gather within these walls do so in order to be protected, God helping them, from the destroying influences that false teachers seek to introduce, thereby destroying the purity of doctrinal understanding and the unity based on such common understanding (Eikelboom, 1998:12-22; Geertsema, $1986: 142-143)$. However, when all is said and done, it is ironic that cultivation of new codes against "discrimination" blurs the search for true equality (Blamires, 1999:99). It is incumbent on believers within an apostolically defined framework to accept those who do not desire to fit in the framework, yet want to be in the group. Indeed, more often than not, they bore from within (Molnar, 2003:3), exposing the counterfeit unity for what it is. 


\subsubsection{Reformed view of members in other denominations}

The accusation has been fielded against reformed church members that they claim that there are no true believers outside the reformed church. This is not the reformed position. Regarding outsiders, all that the reformed position declares is that it is not its business. If there are true believers, then they ought to join the true church wherever she may be found. Nevertheless, it is acknowledged that there will be true believers apart from the true congregation (Belgic Confession, art. 27-29). Such believers fall outside the jurisdiction of the reformed ecclesiastical fellowship, and therefore no judgement will be passed regarding these persons (Anon., 1988:4).

The reformed church is concerned with keeping up certain fundamentals that lie at the centre of the Christian faith. With these the life of the church stands or falls, for they are inviolate (De Jong, 1980:47). From the standpoint of the reformed person it must be recognised that there are those who will reject some points of reformed teaching (e.g. Reformed Baptists, who will hold to the five points of Calvinism as explained in the Canons of Dort, but will reject infant baptism as unbiblical), just as consciously as the reformed person will hold to these same points (Murray, 1976:286). Such persons fall outside the judicial unity professed within the reformed church system (Anon., 1988:4).

\section{Polemic of the wide-embrace proponents}

\subsection{Some historical consequences of confessional tolerance}

Harold Lindsell shows that Princeton Theological Seminary was the centre of theological orthodoxy in the US Presbyterian Church for years. Among its giants were men like Green, Hodge, and Warfield. They are gone, and the institution that once stood for historic evangelical Christianity is an inclusivistic school that has room for a variety of viewpoints that contradict each other. It has no integrated theology that can stand up in the face of the law of internal contradiction (Lindsell, 1976:197). Benjamin Warfield (quoted in Kelly, 1982-1983:154) wrote, "What strikes me today is the incomplete and fragmentary character of our faith: the lack of precision in our Christian conceptions. To these fluid Christian convictions, there necessarily corresponds a lowered Christian life." Van Til, (1974:4) echoing Warfield and militating against proposed toning down of the Westminster Confession by the United Presbyterian Church, declares that what the church needs is a more exact formulation of its doctrines against heresies as they appear in 
every new and changing form, and a fuller statement of Biblical truth.

At its annual meeting in 2005, the Reformed Church of America, one of the nation's venerable, old-line Protestant denominations, almost split over the issue of homosexuality and sin. The church leaders decided to proclaim homosexuality a non-issue, to allow the denomination to focus on a matter that church leaders considered far more critical: basic survival. The roll of the Reformed Church of America has been deteriorating steadily for two decades. The solution is sought in evangelising unchurched citizens. Yet, the decline continues, with a 10000 membership drop in just the last two years (Gibson, 1995). From the report it was evident that a more tolerant application of confessional premises achieved exactly the opposite of what was being targeted: membership declined rather than increased. Notably, covenantal membership, generational membership, was lost.

\subsection{Current arguments against perceived rigorism}

The sermon entitled Mission without walls, addresses Luke 14:1-24. The preacher declares that the church is an alien environment to unbelievers and that they will feel very uncomfortable unless the church makes them feel comfortable and embraces them with unconditional love (Douma, 2006:6). That sounds enticing. Yet, when inviting people from all over the place to a banquet, it still holds true that the invitees will dine on that which is being served up, and in the case of the Lord's invitation, the serving is the apostolic teaching on which to feast. The walls do have a function of protection. The Lord Himself repeatedly assures his church that He places a wall around her and places watchmen on her towers (cf. Is. $5: 1-7)$. Geertsema reminds the reader that separating church walls are a matter of obedience to God's Word and is in accordance to the adopted confession of the church, which is based on Scripture. The churches should maintain those walls, both for the church federation and for individual members (Geertsema, 1986:142-143). Those called to the banquet have their feast within the parameters of what is offered by the host; in terms of the church, those who enter into membership do so within the framework of acceptance of apostolic doctrine.

Another accusation that is being levelled at those who hold to membership only for persons who agree with the confession, is voiced as follows: our practice concerning church membership can be either too loose (indifferent) or too restrictive (rigorous). 
Membership in the visible church community cannot be determined by our own rules and regulations or by the autonomous decisions of Christian leaders, but by the authority of Christ. We are obliged to receive all whom Christ instructs us to receive. We must avoid the twin errors of indifference and rigorism. About indifference one can say the following: if we do not require profession or credible evidence of repentance, we show indifference. We do not take seriously the fact that Christ rebukes sin. As to rigorism: we raise our standards higher than Christ raises them to exclude as many hypocrites and immature believers as possible. The result is that we require immediately the maturity that Christ normally causes through gradual growth. Rigorism misunderstands Christian growth and perseverance. It has a false conception of the purity of the church. It has too much confidence in the ability of leaders to set the standards, and simultaneously too little confidence in the power of the Holy Spirit within the community to bring about growth or to bring about exclusion in the case of a false profession. Therefore, we must not wait until people agree with us in every point of doctrine before being willing to recognise them as Christians and admit them into membership with us. If we recognise people as Christians but refuse them admission to membership, then we fail to receive those whom Christ receives, and our church has become a sect that defines its membership differently from the way Christ defines it. Rather, let us take the qualifications outlined in Belgic Confession, article 29 as a good guide as to whom we can admit to membership.

This objection is serious, and its justification is founded on interpretation and application of the Belgic Confession, article 29. Article 29 defines the marks of the true church (as opposed to the false church), which are:

The church engages in pure preaching of the gospel; it makes use of the pure administration of the sacraments as Christ instituted them; it practises church discipline for correcting faults.

Article 29 then goes on to define those who should be counted as members of the true church:

As for those who can belong to the church, we can recognise them by the distinguishing marks of Christians: namely by faith, and by their fleeing from sin and pursuing righteousness, once they have received the one and only Saviour Jesus Christ. They love the true God and their neighbours, without turning to the right or left, and they crucify the flesh and its works. Though great weakness remains in them, they fight against it by the 
Spirit all the days of their lives, appealing constantly to the blood, suffering, death and obedience of the Lord Jesus, in whom they have forgiveness of their sins through faith in Him.

The argument appears, at first reading, very convincing. Indeed, membership should be determined according to the standards of Scripture, rather than by the dictates of men. The question that beckons then is what the standards of Scripture actually are. The Belgic Confession enumerates those standards in shorthand. Yet, when using a particular denominator, such a denominator requires content. Without giving meaning to the word, it is just that, a word (Snook, 2005:2). Reformed believers would agree with the summation of the Belgic Confession here. But it is necessary, from both the teaching and governing ministry, as well as from the congregational membership perspective, actually to define what the Bible means by the expressions used in this confession.

A name in the Bible is full of meaning, conveying elaborate theology or redemptive history, thereby being more than just a name. An example, among many, can be found in Ruth 1:20, where Naomi whose name means Pleasant - tells acquaintances to call her Mara, which means Bitter, on account of the fact that the Lord had dealt bitterly with her. The names convey the state in which she found herself at various times in her life - initially in the covenant of God, next outside that covenant with all the concomitant bitter experiences.

In a similar manner, certain concepts need to be given content according to a particular framework in order to become meaningful. The apostle James makes a very telling statement regarding this issue as he addresses people who say that they believe in one God. "Thou believest that there is one God; thou doest well: the devils also believe, and tremble" (Jam. 1:20-KJV). The point is that professing a name or faith is meaningless without content.

In article 29 of the Belgic Confession the words are always meant to be understood in the context of apostolic instruction. Maintenance of this instruction is the confession's very reason for being (Anon., 1976:69). Therefore, pure preaching should adhere to the doctrine set forth by the apostles, sacraments are held according to the instruction of Christ and his apostles; discipline is exercised in line with Scriptural dictates, by those who exercise leadership in the church. The parameters for church governance and pastoral dealings are delineated in that way. 
As for the believers in the congregation, they are inclusive parts of the body that we call the church. They are all, including the leadership, distinguishable by their adherence to a particular belief. This belief that binds them together to each other and to their leadership - the church corporate in the local or denominational situation (Murray, 1964:341) - must be a belief explicated in accordance with the teachings of the apostles. Note Paul's anger the moment certain believers draw away from these teachings (Gal. 1:6-12). These apostolic teachings are summarised in the confessions in which the reformed church finds its purity of teaching and its unity. This is the realm in which the church is called to operate harmoniously.

In terms of ethical thinking, there is a rather confounding incongruence in declaring that a person is eligible for membership while merely professing Christ and not necessarily understanding and agreeing to the confessional position of the reformed church.

From a purely intellectual viewpoint, it would appear much simpler to assess a professed adherence to a summary of Biblical teaching than to admit a person merely on an understanding of salvation in Christ. If the requirement is not full Biblical understanding, and if the requirement is not a summary understanding, it must be asked what remains. It follows then, that it is up to the leadership of the church to decide what remains, and that this can only amount to professing Christ coupled with moralistic uprightness, devoid of apostolic meaning. It would appear that such a church has ended up in subjectivism. Ethically, the thinking has become warped, because the tendencies of the post-Christian mind to whittle away distinctions, to abolish boundaries, to intermingle contrasts, run counter to apostolic directives, and yet have made their influence felt in the church (Blamires, 1999:206). The very effort to be objective and Christ-obeying has turned on itself. The accusation has actually turned on those who propose invitation to membership on the basis of professing Christ (without articulating what this means as per the apostles) and honourable living - which cannot be separated from doctrinal rightness. Word and deed go together (Bavinck, 1980:40).

The objection has been raised that a new and aspiring communicant cannot be expected to know, understand and agree to all the confessional points (De Hoog, 2006:2-7). Yet, this is exactly what is being expected of covenant youth who seeks communicant membership. These baptised members receive regular training to gain understanding of the confessions; they are taught that the confessions set forth Biblical doctrine and are shown how it is done. 
At a certain time, these young people are actually examined by the elders regarding their understanding. Those who seek membership from outside the reformed church may equally be expected to study the confessions, so that they may know to what they bind themselves. Failure to operate in that manner creates double standards and varying types of membership: one type holds fully to the confessions, another holds to some chosen part of the confessions, this carrying the approval of the elders (Bavinck, 1980:82).

Furthermore, it is not an overstatement to maintain that the confessions are magnificent in their simplicity, easily understood and Biblically corroborated (Flikkema, 2004:1; Haak, 1999:2; Williamson, 1995:4). For that reason it is not unreasonable to expect that a prospective member study the confessions and be instructed in them (most, if not all, reformed churches include catechetical teaching in the content of the call issued to a minister of the Word) to the point that either rejection or full agreement is arrived at. Thus, members continue to be in unity regarding professed doctrine. Resultantly, shepherding of the flock by the elders can be done on the basis of objectively agreed-upon forms of unity.

\section{Conclusion}

It is not too rigorous to invite people to the banquet of apostolic doctrine and to create in people, whether they have grown up as covenant children or whether they have come in from outside the reformed church, a clear understanding of the sublime heritage of which reformed churches are the custodians. It is an enriching privilege to be brought back to the apostolic teachings that the forms of unity seek to protect.

The basic tenets of the confessions, such as the Heidelberg Catechism, the Belgic Confession and the Canons of Dort, are well within a Christian's potential, intellectual grasp. Admittedly, the opus magnum of the reformed heritage, the Westminster Confession, may require somewhat more effort, but also this confession is easily understood in terms of what it calls believers to accept as truth.

If a reformed church calls itself a confessional church, then this means that those who are in that church agree with the confessions with which the church operates. They agree because they have come to know that the confessions are a necessary protection against untruth, a bond of unity in which they may hold each other to 
account, and a bond that they may celebrate around the Lord's Supper table.

The overseers of the church are called to protect the flock from doctrinal error; they are also called to check on the spiritual health of the members entrusted to their care. The markers according to which the elders are able to ascertain how a member functions in doctrine and life are objective, given by God in Scripture and summarised in the confessional heritage. They are the doctrinal teachings by which the members are called to live (Geertsema, 1986:142-143).

For the members the confessions are a blessing beyond compare, as these confessions crystallise what they belief, giving ability to articulate the certainty of faith that each child of God craves to have (Bavinck, 1980:25).

\section{List of references}

ANON. 1976. Psalter hymnal, doctrinal standards and liturgy of the Christian Reformed Church. Grand Rapids: Board of Publications of the Christian Reformed Church.

ANON. 1988. The church concept of the reformed churches. Kampen: Theologische Hogeschool Kampen. (Theological Seminary Position Paper.)

BAVINCK, H. 1980. The certainty of faith. St. Catharines: Paidea.

BLAMIRES, H. 1999. The post-Christian mind: exposing its destructive agenda. Ann Arbor: Servant Publications.

DE HOOG, J. 2006. Indifferentism and rigorism in the church. Canberra: Christian Reformed Churches of Australia.

DE JONG, P.Y. 1980. The church's witness to the world. St. Catharines: Paidea.

DE TOCQUEVILLE, A. 1832. Democracy in America. New York: New American Library of America.

DOUMA, L. 2006. Mission without walls. Canberra: Christian Reformed Churches of Australia.

EIKELBOOM, J. 1998. Acts of synod Launceston: evaluation of F.J. van Hulst's teachings. (In Synod Free Reformed Churches of Australia. Launceston: Free Reformed Churches of Australia. p. 2.)

EYRES, L.R. 1983. The elders in the church. Phillipsburg: Presbyterian \& Reformed Publishing.

FLIKKEMA, R. 2004. Predestination: a Scriptural and confessional truth. http://www.reformedwitness.org/pmphltlst/Prdstntn.html Date of access: 7 March.

FLINN, M. 1985. The importance of doctrine. Pukekohe: Reformed Churches of New Zealand.

GANZ, R. 2005. What is a reformed church? http:/www.reformed.com/ triangle/t_ganz.html Date of access: 3 March. 
GEERTSEMA, J. 1986. A closed Lord's Supper table is not proof of a sectarian spirit but shows ecclesiastical faithfulness. Clarion, 35:142-143.

GIBSON, D. 1995. Reformed Church on membership mission. The Record: 3, 18 Jun.

GREEN, M. \& McGRATH, A. 1995. How shall we reach them? Nashville: Thomas Nelson.

GRESHAM MACHEN, J. 1936. The creeds and doctrinal advance. The Presbyterian guardian, 4:35-38.

GRESHAM MACHEN, J. 1940. The progress of Christian doctrine. The Presbyterian guardian, 7:1, 2, 8-10.

HAAK, C. 1999. I was glad to go to God's House. http://www.prca.org/ refwitness/1999/1999jul11.html Date of access: 7 March 1999.

HENRY, M. 1721. Commentary on the whole Bible. Vol. V: Matthew to John. New Jersey: Revell.

HOSPERS, G.H. 1924. Creeds and standards: their significance and functioning. http://www.the-highway.com/articleFeb99.html Date of access: 4 March 1999.

JONES, P. 2001. Pagans in the pews. Ventura: Regal Books.

KELLY, D. 1982-1983. You can't split rotten wood. Vallecito: Chalcedon Ministries.

LINDSELL, H. 1976. Battle for the Bible. Grand Rapids: Zondervan.

McGRATH, A. 1995. Explaining your faith. Leicester: InterVarsity.

MOLNAR, T. 2003. They bore from within: ecumenism of new reformation. Faith and freedom, 6:3.

MURRAY, J. 1964. The nature and unity of the church. (In Murray, John. Collected writings of John Murray. Vol. 2: Select lectures in systematic theology. Edinburgh: The Banner of Truth Trust.)

MURRAY, J. 1976. Collected writings of John Murray: the claims of truth. Edinburgh: The Banner of Truth Trust.

SNOOK, I. 2005. Critique on Lovat's view. Speech in Values Education Forum Canberra. (Unpublished Conference Address.)

VAN TIL, C. 1974. An introduction to systematic theology. Philadelphia: Presbyterian \& Reformed Publishing.

WEAVER, R.M. 1984. Ideas have consequences. Chicago: University of Chicago Press.

WILLIAMSON, G.I. 1995. How I came to the conclusion that our reformed fathers were right about worship. (In Worship seminar. San Francisco: First Orthodox Presbyterian Church USA, 12-14 May.)

\section{Key concepts:}

apostolic teaching, basic tenets contained in the confessions confessions: normative to combat error

confessions: professed base of unity among reformed church members

confessions: restrictive nature of regarding membership in the reformed church 


\section{Kernbegrippe:}

belydenisse: basis vir eenheid tussen gereformeerde kerklede belydenisse: engheid met betrekking tot lidmaatskap in die gereformeerde kerk

belydenisse: 'n skans teen afdwaling

kernleerstellings van apostoliese leer: bevat in die belydenisse 
